\title{
A csíkmadarasi vasgyártásból visszamaradt leletek anyagszerkezeti vizsgálata
}

\section{Microstructural Characterisation of Archeologic Finds Discovered at the Ironworks in Mădăraș}

\author{
Bitay Enikő, ${ }^{1}$ Márton László, ${ }^{2}$ Talpas János ${ }^{3}$ \\ ${ }^{1}$ Sapientia Erdélyi Magyar Tudományegyetem, Marosvásárhelyi Kar, Marosvásárhely, Románia, \\ ebitay@ms.sapientia.ro \\ ${ }^{2}$ Erdélyi Múzeum-Egyesület, Müszaki Tudományok Szakosztálya, Kolozsvár, Románia, martonlb@yahoo.com \\ ${ }^{3}$ Babeş-Bolyai Tudományegyetem, Kolozsvár, Románia, talpasjanos@gmail.com
}

\begin{abstract}
In the middle of the 16th century the ironworks of Mădăraș was one of the important centres of iron production. During its one and a half century lifespan its output provided a significant part of Transylvania's iron supply. While it operated it used up the entire raw material extracted in the iron ore mines of the Felcsík basin. This study presents the reconstructed ground-plan of the ironworks, its layout on the shores of the Mădăraș creek, and the chemical composition and microstructure of the samples discovered during exploration of the location by means of XRF analysis, EDS analysis and metallography. The analysis of the pig iron, the steel and the slag although performed on individual samples, still provides a good approach regarding the products of the ironworks, their chemical composition and microstructural characteristics.
\end{abstract}

Keywords: ironworks, microstructure, metallography, spectrometry, use of waterpower, melting, smithy.

\section{Összefoglalás}

A XVI. század közepén az erdélyi vasgyártás egyik központja a csíkmadarasi hámor volt. Másfél évszázados működése alatt termelése jelentősen hozzájárult Erdély vasszükségletének kielégítéséhez. A csíkmadarasi hámor müködtetése idején a Felcsíki-medence vasérclelőhelyein kitermelt nyersanyag mind a madarasi olvasztóba került. Jelen dolgozat ismerteti a hámor elhelyezkedését a Madaras-patak partján, valamint a metallográfia, az XRF- és az EDS-spektrometria felhasználásával, a terep bejárása során előkerült termékek összetételét és mikroszerkezetét. A nyersvas, az acél és a salak elemzése, bár egyedi minták felhasználásával készült, megközelítő képet nyújt a termékek összetételéről, mikroszerkezeti sajátosságairól.

Kulcsszavak: vashámor, anyagszerkezet, metallográfia, spektrometria, vízenergia-hasznosítás, olvasztókemence, kovácsmühely.

\section{Bevezető}

A fejedelemség korában Székelyföldön a már ismert és az újabban feltárt vasérclelőhelyek körül kiterjedt bányászatról, vasgyártásról és -feldolgozásról korabeli dokumentumok is tanúskodnak [1], [2]. A XVI. század közepén már az erdélyi vasgyártás [3] egyik központja, a csíkmadarasi hámor is termelt [4], [5]. Másfél évszázados fennállása alatt termelése jelentősen hozzájárult Erdély vas szükségletének kielégítéséhez. Jövedelmezősége mellett további jelentősége, hogy Csíkszék tíz helységének lakosai dolgoztak a madarasi vashámorban, ezáltal mentesültek adóterheik alól, mi több, a bányaművelésben dolgozó jó néhány csíki, gyergyói és kászoni személynek Báthory Zsigmond, Erdély fejedelme lófőséget adományozott [6].

Abban az időben már ismert volt, hogy a Hargita csíkmadarasi szakaszán vasérc található. A madarasi hámor tevékenységére az is jellemző, hogy gyakorlatilag az egész Felcsíki-medence vasércbá- 
nyáinak terméke - a vaskő - a hámor nyersanyagaként a madarasi olvasztóba került. 1695-ben kezdetét vette a madarasi vashámor rohamos hanyatlása, és egy 1703-ból származó leltári összeírás már a hámor siralmas állapotát jegyzi. Ekkor csupán 40 forintért adták bérbe, amikor egy ökör piaci ára 10-14 forint volt. 1722-ben, amikor újból bérbe adták, a szerződésben nem szerepel a vasgyártás kifejezés; csupán a területek és a még müködő fürészmalom jelentettek szerződéses értéket.

A hámor folyamatos tevékenysége az 1567 és 1725 közötti időszakra tehető. Megszünését a vasérc hiányának tulajdonították, ami csupán egyike annak a sor hiányosságnak, amelyben az első helyen, kétségen kívül, a hámor gazdáinak téves és helytelen szemlélete állt.

\section{A hámor és termékei}

A csíkmadarasi vashámor müködtetésében korának megfelelő műszaki színvonalú gépeket, szerszámokat és gyártási folyamatot alkalmaztak. A hámortelep ideális termelési feltételét a bő és állandó vízhozamú, gyors folyású patak, a Madaras-patak jelentette. Közel volt a szénégetés alapanyagát, a bükkfát adó erdő, mellette a vasérc lelőhelyei, s végül a salakképző anyag, a mészkő is. Áprilistól novemberig, a fagymentes hónapokban folyamatosan működhetett a hámor.

1673-ban a dolgozók száma 137 személy, ezek közül csupán egy volt a vaskőkereső, akit a mai geológus megfelelőjének tekinthetünk. A bányászok, az olvasztárok, a kovácsok, a fújtatókészítő vargák, a csákányhegyező kovácsok, a vasverők és a szekeresek munkáját két hámori bíró irányította. Jól megszervezett üzem lehetett a csíki vasgyár. A termelt vas mennyisége elérte a 190 mázsát évente, amit, összehasonlítva a vajdahunyadi öt hámor termelésével, azt tapasztaljuk, hogy utóbbiak csupán 118 kilóval termeltek több vasat hetente, mint a csíkmadarasi hámor.

A termékek felett a fejedelmi udvar rendelkezett. Ezeket Radnótra, Görgénybe, Ebesfalvára, Fogarasra irányították, további feldolgozás céljából. Madarason szálvasat, serpenyőket, ágyúgolyót, patkót, patkószeget és mezőgazdasági szerszámokat, eszközöket gyártottak. Kétszáznyolcvan év távlatából megállapítható, hogy a természet átalakító erejének és az emberi nemtörődömségnek az lett a folyománya, hogy ma csak szakember következtethet az egykor virágzó vasgyár méreteire. Egy 1677-ben készített leltár alapján készült az a helyszínrajz, amely először mutatja be a vashámor egykori lehetséges képét (1. ábra).

A helyszínrajz szerint a csíkmadarasi vashámor a Madaras-patak jobb partján helyezkedett el. A patakból leágazó malomárok a ma is fellelhető (az ábrán C jelzésű) egykori kiegyenlítő víztárolóba torkollott, amelynek az volt a szerepe, hogy ál-

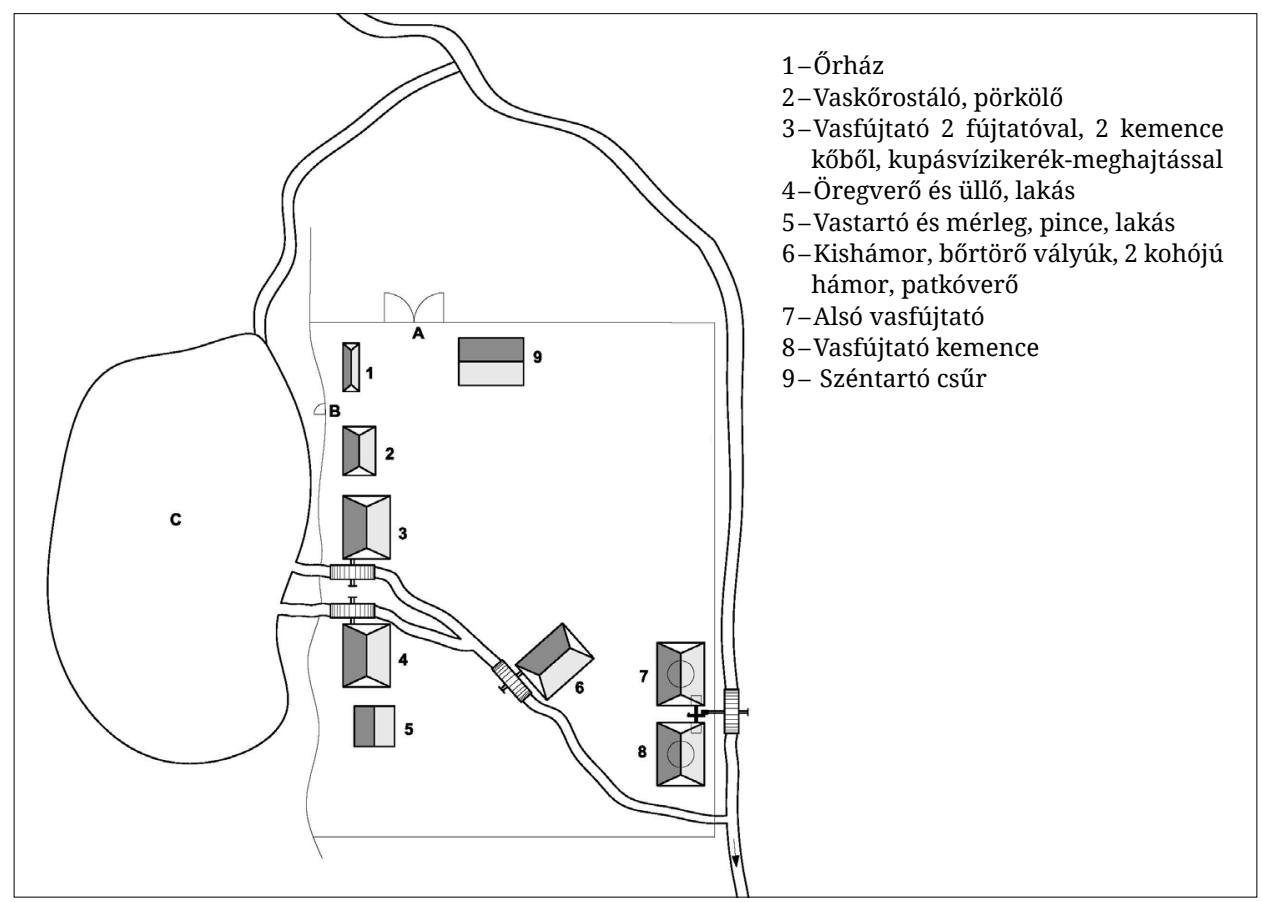

1. ábra. A csíkmadarasi vashámor helyszínrajza 
landó hozammal és állandó nyomással biztosítsa a három vízikerék vízellátását. Egy negyedik vízikerék meghajtását maga a Madaras-patak látta el. A telepen két vasolvasztó kemence működött (3as, 7-es szám jelöli), ezek termelését további feldolgozásra a 4-es és 6-os számmal jelzett kovácsműhelyekbe szállították.

A telepen a vaskőrostáló és a pörkölő (2) előkészítette a kitermelt vasércet a további feldolgozásra, az olvasztásra. Az 5-ös számmal jelzett épület a késztermékraktár volt. A széntartó csűr (9) fogadta a szénszállító szekerek rakományát, a faszenet. A fuvarok az A-val jelzett kapun léptek be az üzem területére. Ezeken kívül néhány épületnek több funkciója is volt, többek között lakások, bőrfeldolgozó mühely stb.

\section{A vashámor anyagmaradványainak elemzése}

Többszöri terepbejárás eredményeként különféle anyagmaradványok kerültek elő: salakmaradék, nyersvasmaradék és acélmaradék.

Ezekből az anyagdarabokból vizsgálati mintákat vágtunk ki, amelyeket Thermo Niton XL3T típusú röntgenfluoreszcencia spektrométerrel (XRF), SPECTROTEST TXC25 típusú optikai emissziós spektrométerrel és Zeiss EVO10 pásztázó elektronmikroszkóp energiadiszperzív spektrométerével (EDS) vegyelemeztünk. A felkutatott anyagminták felületét, illetve metallográfiai csiszolatokon a belső szerkezetét iqualitrol iMet-Y400 és Olympus PMG-3 típusú fémmikroszkóppal, továbbá sztereomikroszkóppal és pásztázó elektronmikroszkóppal vizsgáltuk.

Az 1. táblázat az XRF-es vegyelemzés eredményeit tartalmazza. A három adatsort elemezve a következőket állapíthatjuk meg:

- Az anyagmaradékok vastartalma 38,3-74\% közé esik. Ebben csak az a rendhagyó a mai vaskohászati maradékok összetételi eredményeivel összevetve, hogy a salakmaradék vastartalma 38,3\%, ami a gyenge kinyerés következménye. A salakban jelentős mennyiségü, értékes elemek, pl. Zn, Ni, Sb találhatók, ezek kinyerése a hámor müködése alatt felhalmozódott salakhegyből időszerű feladattá válhat.

- A nyersvasmaradék-mintadarab természetesen már vasban dúsabb: vastartalma 62,1\%-ot tesz ki. Megjegyezzük, hogy a felmért, 5,8\% Si-tartalom is jellemző az öntvényekre. A Cr- és Sb-tartalom nem túl nagy, de éppenséggel lehet a csíkmadarasi vasércek sajátossága. A metallográfiai vizsgálatra előkészített, csak polírozott, tehát nem maratott nyersvasmaradék-mintában jól látható a grafit rozettás eloszlása (lásd a 2.a-b ábrát).

- Az acélmaradék mintadarab XRF-es elemzésében megjelenik a réz (290 ppm), ugyanakkor csökken a nikkel részaránya (38 ppm). A cink, alumínium, ón jelenléte komplex ércre utal, ugyanakkor kuriózum, hogy a vas olvadási hőmérsékletén megmaradtak ezek az elemek. $\mathrm{Az}$ itt előállított acél foszfor- és kéntartalma az XRF-es vizsgálat szerint csekély (a spektrométer nem mutatta ki ezen elemeket), de a metallográfiai vizsgálat és a csiszolatok különböző pontjaiban végzett EDS-analízis világosan mutatja, hogy az összetétel az acélminta csiszolatának különböző pontjaiban változó volt. A szennyezők mennyisége jelentős, és az anyagra a durva salakosság jellemző, ami természetes velejárója a korabeli gyártási technológiának.

A korabeli vasművességre jellemző többszöri felmelegítés és kovácsolás hatására a kezdetben nagyon inhomogén vasanyag homogenizálódhatott, kiégett a grafit és kikovácsolták belőle a salakot; így vált igazi, használható acéltermékké. Ha nagyobb mennyiségben kerülne elő nyersvas és acéltermék, amit elemezni lehetne, az eredmények is nagyobb pontosságúak lennének. Talán egy átfogó ásatás hozhatna felszínre újabb vashulladékokat, bár a valószínűsége kicsi, tudva azt, hogy a leltárok pl. a bejárati kapu elemeinek rögzítésénél használt vasszegeket darabonként tartalmazzák.

1. táblázat. Az XRF-es elemzés eredményei (\%)

\begin{tabular}{|l|c|c|c|c|c|c|c|c|c|c|c|c|c|c|}
\hline & Fe & Mn & $\mathbf{S i}$ & $\mathbf{S}$ & $\mathbf{P}$ & $\mathbf{C r}$ & $\mathbf{N i}$ & $\mathbf{C u}$ & $\mathbf{Z n}$ & $\mathbf{M o}$ & $\mathbf{A l}$ & $\mathbf{S b}$ & $\mathbf{S n}$ & $\mathbf{A s}$ \\
\hline $\begin{array}{l}\text { Salak- } \\
\text { maradék }\end{array}$ & 38,3 & 3,2 & & & & & 0,0345 & 0,0092 & 0,0712 & & & 0,0077 & & 0,0061 \\
\hline $\begin{array}{l}\text { Nyersvas- } \\
\text { maradék }\end{array}$ & 62,1 & 0,75 & 5,8 & 0,11 & 0,76 & 0,0498 & & & & & & 0,0109 & & \\
\hline $\begin{array}{l}\text { Acél- } \\
\text { maradék }\end{array}$ & 74 & & & & & & 0,0038 & 0,0290 & 0,0100 & 0,0020 & 0,0100 & & 0,0100 & \\
\hline
\end{tabular}


a)
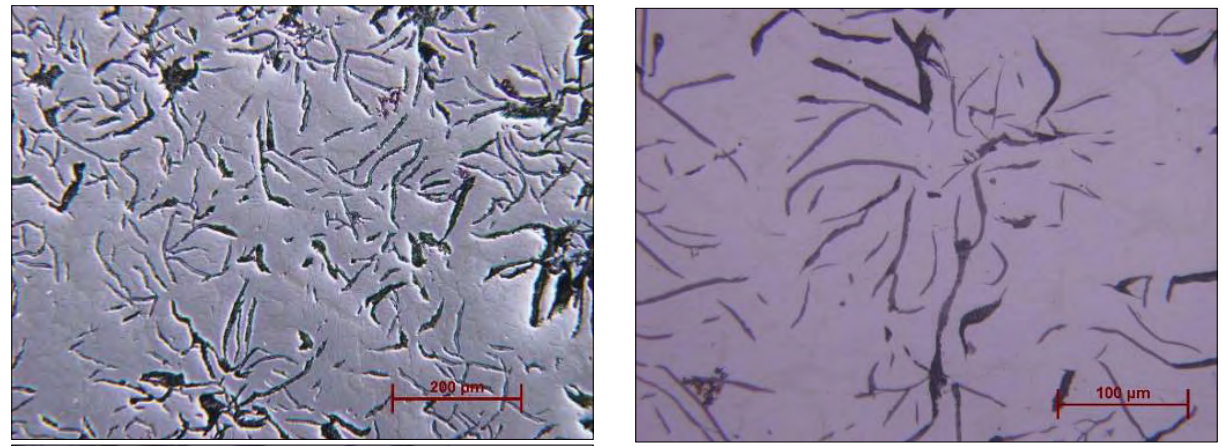

b)

c)
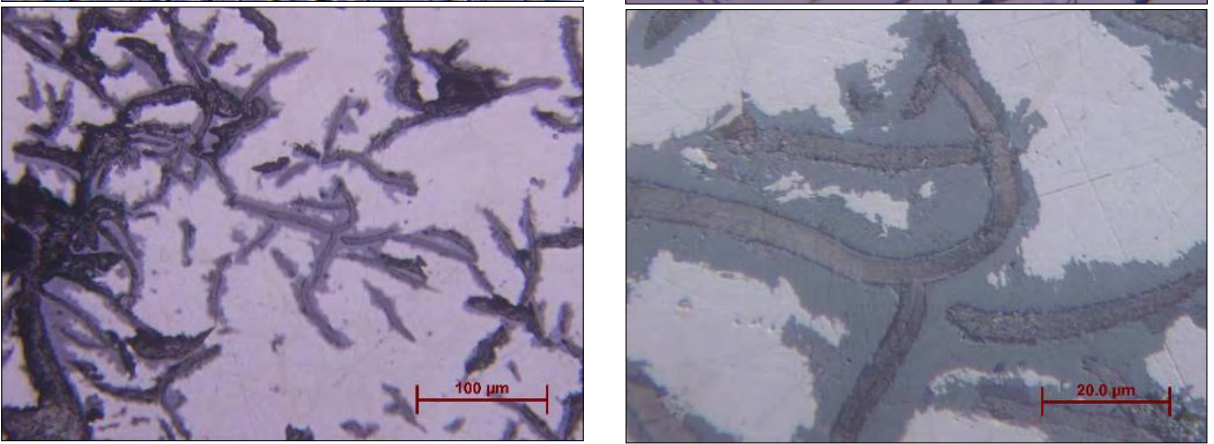

d)

2. ábra. A nyersvasmaradék mikroszerkezete polírozott állapotban, a minta belső részén $(a-b)$, valamint a korrodálódott felület közelében (c-d)
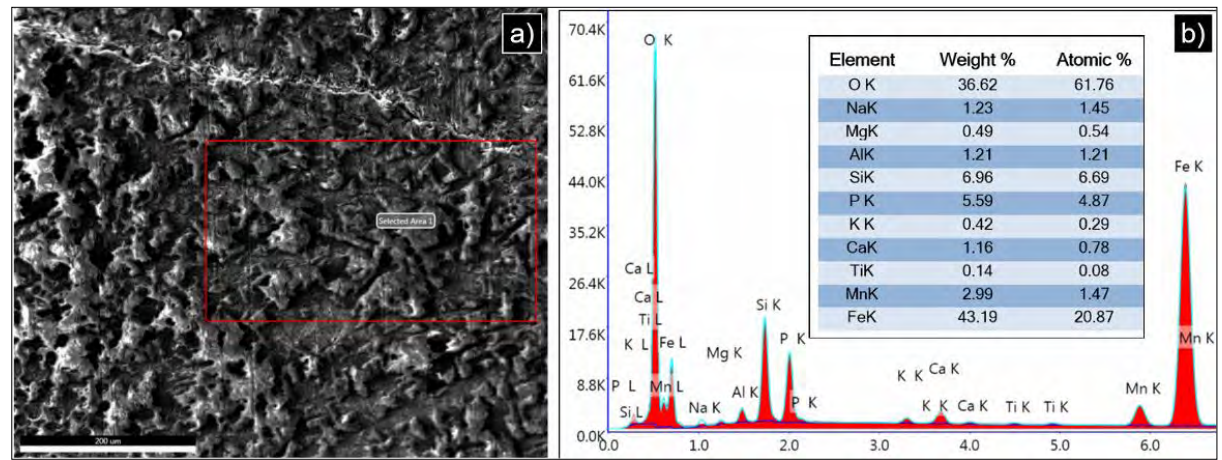

3. ábra. A salakmaradék töretfelületének egy részlete (a), továbbá a rajta bejelölt területről felvett EDS-elemzés intenzitásdiagramja a kémiai összetétellel (b)

4. Az anyagmaradványok mikroszerkezetének vizsgálata

\subsection{A salakmaradék vizsgálata}

A helyszíni gyűjtés során talált anyagmaradékok közül a salakmaradék kémiai összetételét EDS-analízissel is meghatároztuk, a 3a. ábrán látható felületet vizsgálva, amely a salakdarabnak a belső töretfelülete. Az EDS-analízis intenzitásdiagramja és az abból meghatározott összetétel a 3b. ábrán látható. Az EDS-elemzést több területen is megismételve azt kaptuk, hogy tömegrészarányban a Fe-tartalom rendre $42-44 \%$, a Si-tarta- lom kb. 7\%, a Mn-tartalom 2-3\%, és 1\%-nál több alumínium is jelen van a salakban. Az XRF-es elemzéssel összevetve feltűnő, hogy az EDS-elemzés jóval nagyobb mennyiséget mér a foszforra (5-6\%); ez az eltérés rávilágít az XRF-es elemzés korlátaira [7-10].

\subsection{A nyersvasmaradék vizsgálata}

A leletből kivett anyagvizsgálati mintából metallográfiai csiszolatot készítettünk, amelyet polírozott állapotban és 4\%-os Nital marószerrel marva is vizsgáltunk, fémmikroszkóppal és pásztázó elektronmikroszkóppal egyaránt. A 2. ábrán az 
a)

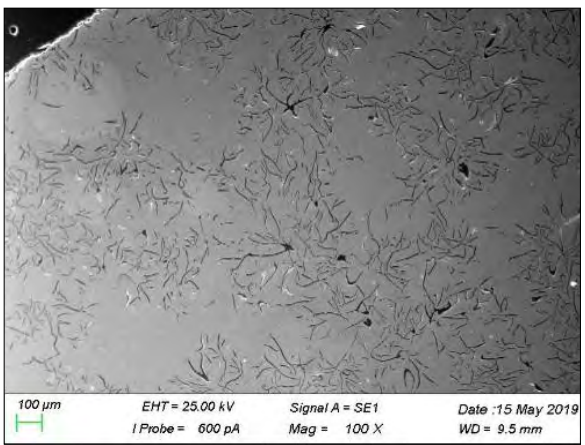

4. ábra. A nyersvasmaradék szövetszerkezete

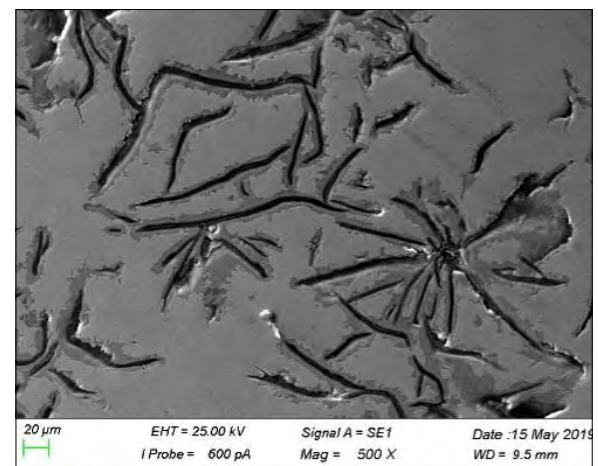

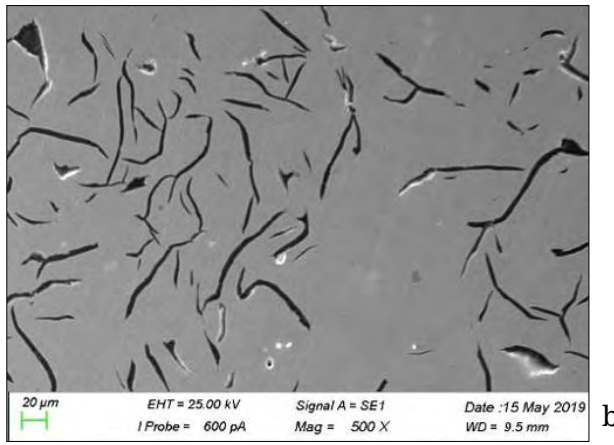

b)

5. ábra. A nyersvasmaradék felületközeli részének szövetszerkezete polírozott állapotban, szekunderelektron-képen

ISO 945-1:2019 szabvány szerint azonosítható a lemezes szerkezetű grafit alakja, eloszlása és mérete. A grafit alakja az I. és a II. osztály határára esik, eloszlását tekintve a B osztályba (rozettás grafit), mérete alapján pedig a 3. és a 4 . fokozat határára sorolható a nyolcfokozatú skálán. A fellelt minta felülete közelében a ferrit és a grafit fázishatára mentén széles sávban korrodálódott az anyag, ez látható a 2.c-d ábrán.

A polírozott állapotban végzett vizsgálat csak a grafit szerkezetének meghatározását teszi lehetővé, a mátrix azonosításához a maratás elengedhetetlen [11]. A maratás azonban roncsolhatja a felületközeli rétegben a grafitlemezek határfelülete mentén korrodálódott részeket, ezért a maratás előtt végeztük el a pásztázó elektronmikroszkóp EDS-elemzőjével az anyag egyes, jellegzetes pontjai kémiai összetételének meghatározását. A 4. ábra mutatja a polírozott állapotú minta szekunderelektron-képét. A 4.b ábrán látható felület egészét vizsgálva a fő összetevők mennyisége a vas és a szén nélkül: $\mathrm{Si}=0,77 \%, \mathrm{Mn}=1,17 \%, \mathrm{P}=1,72 \%$.

A felületközeli rész szövetképét mutatja az 5. ábra. A grafitlemezek fázishatárán korróziótermék képződött, amelyben az EDS-elemzés atomrészhányadban $43 \%$ vasat és $56 \%$ oxigént mutatott ki, amely arány közel áll a magnetit Fe/O arányához. Az 5.b ábra egy részletét kinagyítva mutatja a 6. ábra, amelyen jól látható egy foszfideutektikumot tartalmazó rész. Az eutektikumban a foszfor atomi részaránya $17 \%$, a foszfidlemezben pedig $25 \%$.

A Nitallal végzett maratás kitűnően előhívta a szövetszerkezet vasdús szövetelemeinek morfológiai jellemzőit. A 7. ábra szövetképeiből kitűnik, hogy a megszilárdulás során a rozettás grafit kiválása után az eutektikus hőmérsékletre hűlő olvadék mintegy 3/4-e ausztenitté alakult. Az olvadék maradékából lédeburit alakult ki. A lehűlés eléggé gyors volt, amit az jelez, hogy mind a lédeburit, mind pedig az ausztenitből keletkezett perlit szerkezete rendkívül finom.

\subsection{Az acélmaradék vizsgálata}

Ebből az anyagvizsgálati mintából is metallográfiai csiszolatot készítettünk, majd polírozott állapotban és Nital marószerrel végzett maratás után is vizsgáltuk. A 8. ábra szövetképei arról tanúskodnak, hogy a lelet anyaga jelentős átalakításokon esett át a nyersvassá alakítást követően. Az így kialakult szövetszerkezet fő jellemzői az alábbiak: 
a)
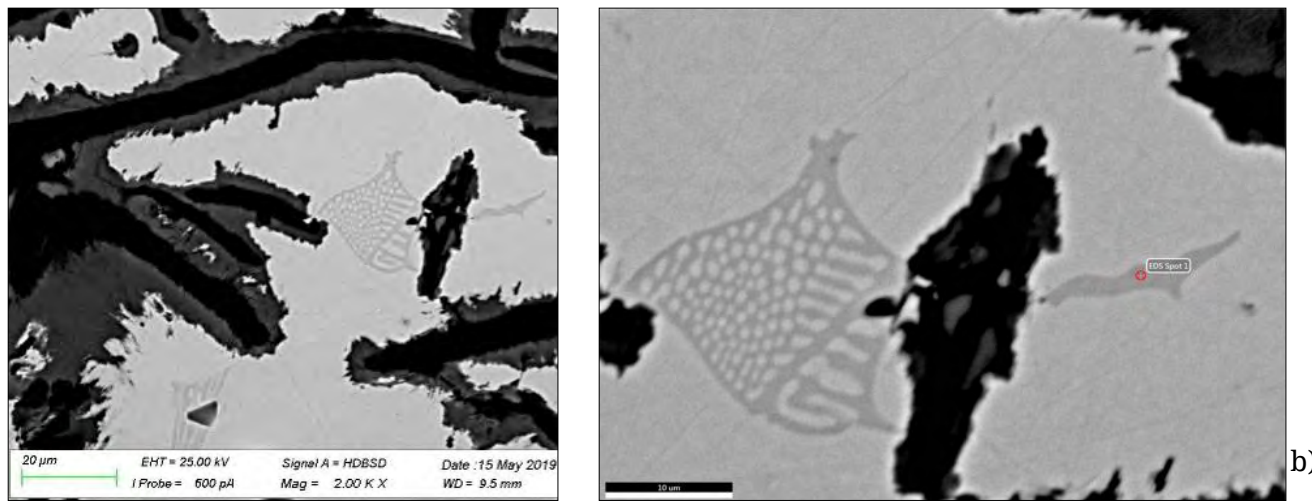

6. ábra. A szövetszerkezet foszfideutektikumot tartalmazó részlete szekunderelektron-képen
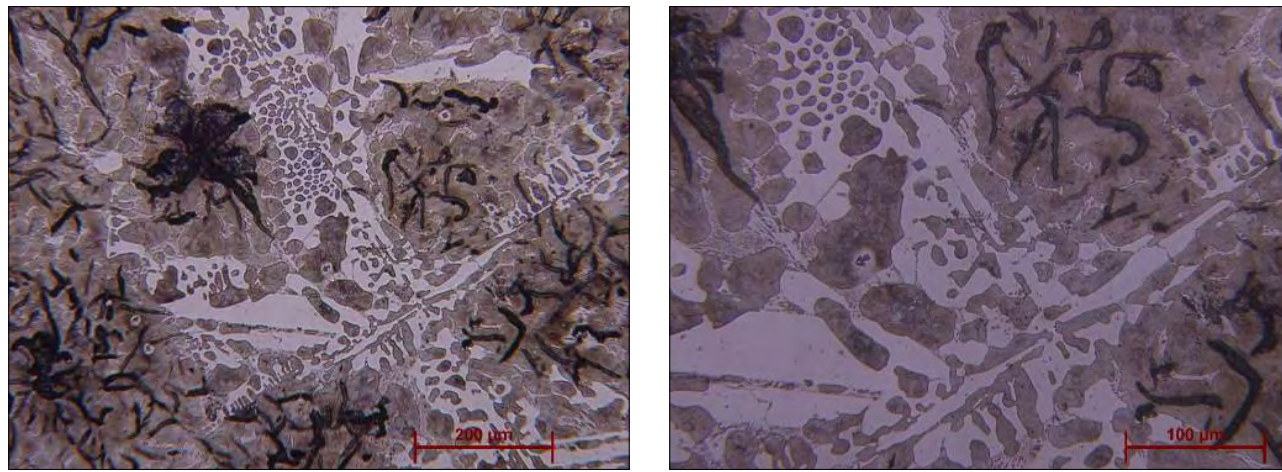

b)

c)
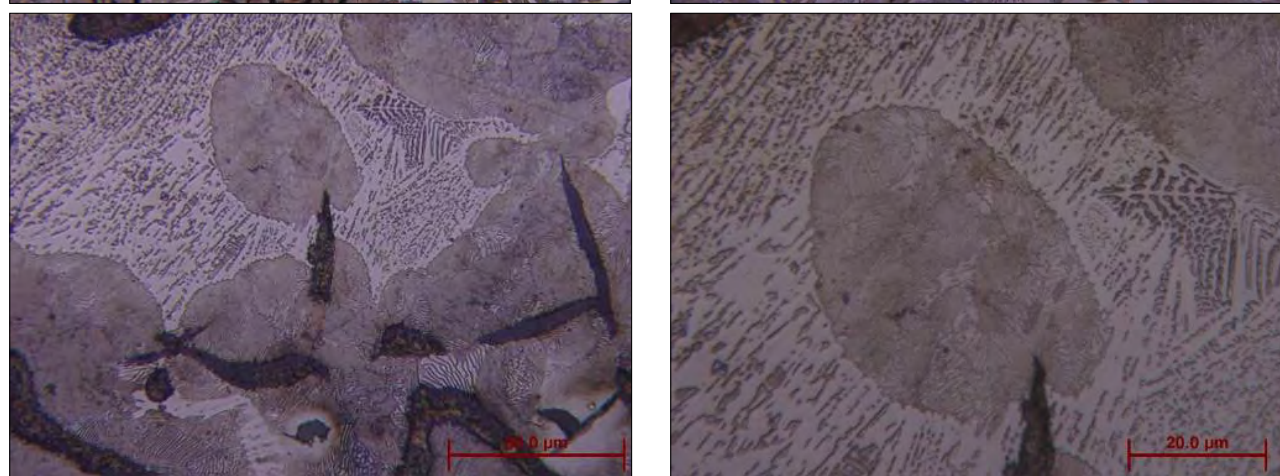

d)
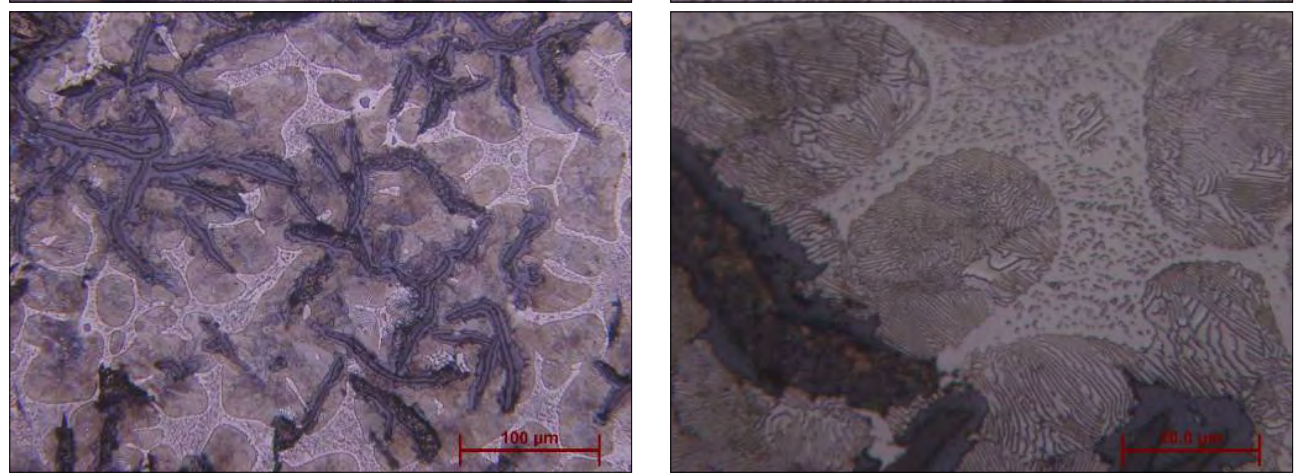

7. ábra. A nyersvasmaradék mikroszerkezete polírozott állapotban, a minta belső részén ( $a-b)$, valamint a korrodálódott felület közelében (c-d) 
a) Az anyag a vastagság mentén nagyon erősen eltérő széntartalmú zónákra tagolódik. A kis C-tartalmú részeken csak a ferritszemcsék szemcsehatárai maródtak meg, míg a sötétre maródott zónákban nagy a C-tartalom, mivel itt csaknem teljesen eutektoidos az anyag összetétele. A 8.eábrán pl. a perlites tartományok alkotják a szövetnek kb. a 95\%-át, a proeutektoidos ferrit csak kb. 5\%-ot tesz ki.

b) Az anyag nagyon jelentős mértékben salakos, a salakzárványok főleg a felülethez közeli sávokban dúsulnak. Itt, a felületközeli zónában viszont a C-tartalom 0,037\%-ra csökkent a SPECTROTEST-es mérés szerint. A szén mellett a $\mathrm{Si}$, a Mn és a kén szinte teljesen kiégett, és a P-tartalom is

a)

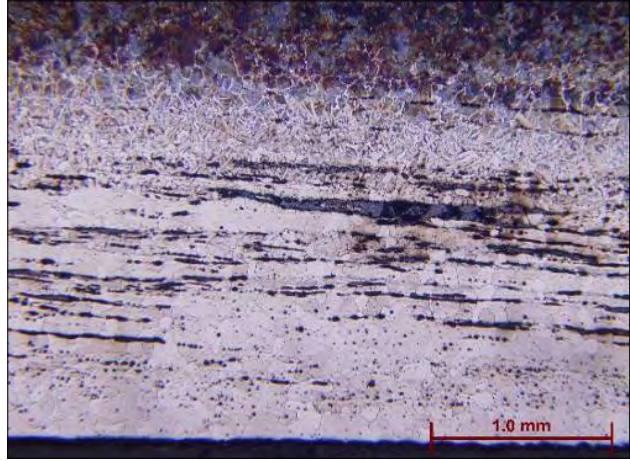

c)

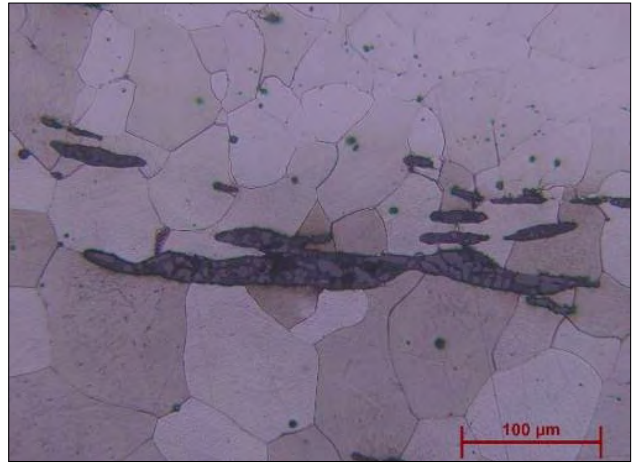

e)

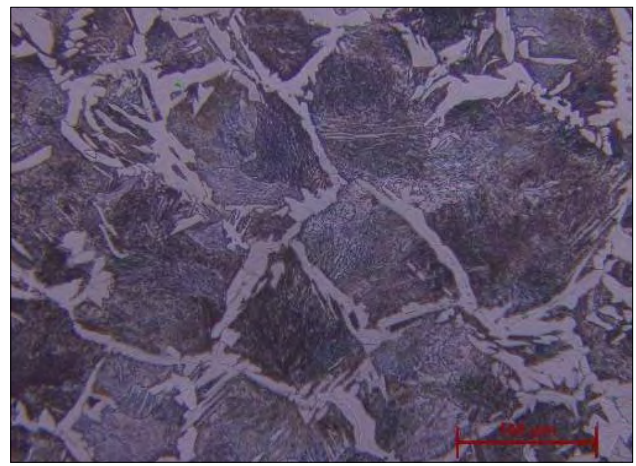

csak 0,079 \%. Az összetevők kiégése és a jelentős mértékű salakosság arra utal, hogy a kovácsolást egészen nagy hőmérsékleten és hosszan tartó izzítással végezték, a felületet pedig nem tudták rendesen megvédeni a revésedéstől.

c) A kovácsolás okozta képlékeny alakváltozás mértéke jelentős volt.

d) A végső hőkezeltségi állapot a dekarbonizálódott részeken a teljes lágyításnak felel meg (8.c ábra), a kb. $12 \mathrm{~mm}$ vastag minta nagy C-tartalmú rétegeiben (9.a ábra) pedig a nem túl erélyes hütés hatására kialakuló, tűs ferrites és finomlemezes perlites szerkezetnek. A 9.b ábrán egy vastag salakréteg belső szerkezete látható, a minta polírozott (maratlan) állapotában.

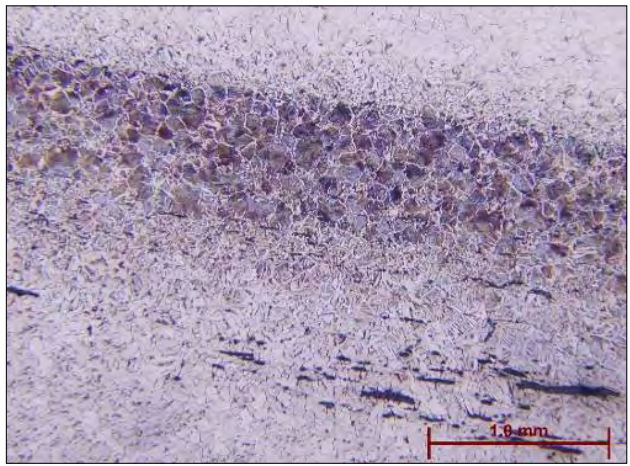

b)

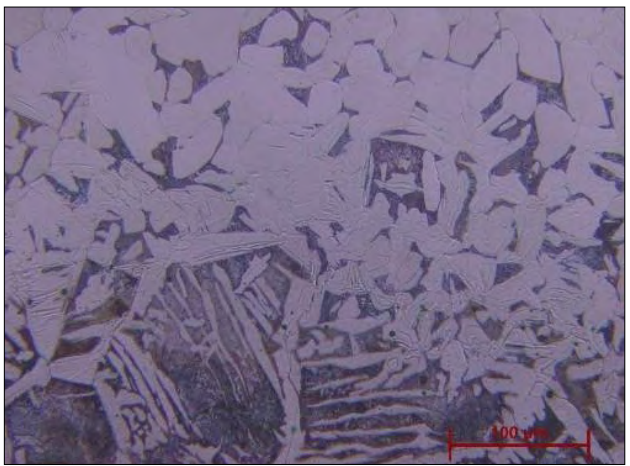

d)

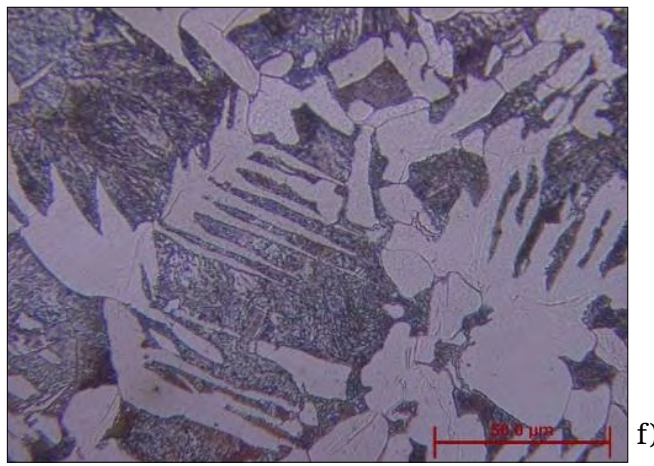

8. ábra. Az acélmaradék-minta mikroszerkezete a vastagság mentén kialakult egyes sávokban (marószer: Nital-4) 
a)
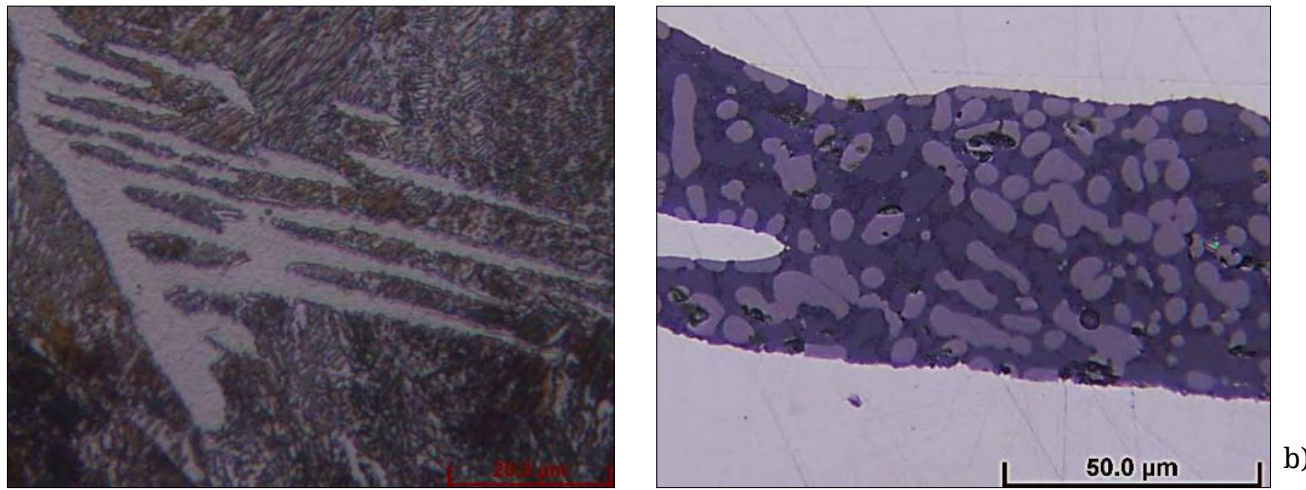

9. ábra. a) Az acélmaradék-minta mikroszerkezete a nagy C-tartalmú rétegben (marószer: Nital-4); b) A salakzárvány mikroszerkezete polírozott állapotban

\section{Következtetések}

Ez a munkánk az első kísérlet a 16. században működő csíkmadarasi vasgyártás telephelyének rekonstruálására, a hámor termékeinek anyagtudományi módszerekkel való jellemzésére. Az elemzések arra utalnak, hogy a felhasznált vasérc, a sziderit, nem egyedüli ásványként volt jelen egy komplex ércben, hanem andezittufák, mészkő és dolomit, kristályos palák stb. kísérték. Ezekből származnak azok az elemek, amelyek a csíkmadarasi vas összetételét egyedivé teszik.

A leletek összetételének és szövetszerkezetének vizsgálata azt mutatja, hogy a csíkmadarasi hámor acéltermékeire - mai szemmel nézve - összetételben és szövetszerkezetben egyaránt jelentős mértékű inhomogenitás jellemző. Ez nyilvánvalóan kihatott a termékek mechanikai tulajdonságaira is, de nagyon valószínü, hogy az adott kor technológiai lehetőségei nem is nagyon tettek lehetővé jobb minőségű anyagot az akkori tömegtermékek gyártásában.

A hámor 170 éven át tartó működése alatt jelentős mennyiségü, értékes elemeket tartalmazó (Zn, $\mathrm{Ni}$, Sb stb.) salak halmozódott fel, amelyből ezen elemek kinyerése időszerü feladattá válhat.

\section{Szakirodalmi hivatkozások}

[1] Guran M.: Fierul. Editura Tehnică, Bucureşti, 1978.

[2] Szakács A.: The siderit of the neogene volcanism-related ironores in the East Carpathians (Romania). Mineralogy and chemical features. Romanian Journal of Mineralogy, 75/1. (1992).
[3] Latinák Gy.: A vajdahunyadi m. kir. vasgyár és tartozékai I-IV. Bányászati és Kohászati Lapok, 39/2. (1906) 2-48, 73-99, 137-172, 203-242.

[4] Jakab Gy.: Székelyföld érctelepei. Tanulmányok Erdély földtanából. Földtani közlöny, 135/3. (2005) 459-478.

[5] Pataki J.: A csíki vashámor a XVII. század második felében. Csíkszereda, 1971. 48-54.

[6] Orbán B.: Székelyföld leírása I. Pest, 1863, Csíkszék, 57-72.

[7] Rousseau R. M.: Detection limit and estimate of uncertainty of analytical XRF results. The Rigaku Journal, 18/2. (2001) 33-47.

[8] Kadachi A. N., Al-Eshaikh M. A.: Limits of detection in XRF spectroscopy. X-ray Spectrometry, 41/5. (2012) 350-354.

https://doi.org/10.1002/xrs.2412

[9] Borkhodoev V. Y.: Estimation of limits of detection and determination in $X$-ray fluorescence analysis by the dependence of the relative standard deviation on analyte concentration. Journal of Analytical Chemistry, 71/9. (2016) 872-877. https://doi.org/10.1134/S1061934816070054

[10] Liss B., Levy T. E.: Using X-Ray Fluorescence to Examine Ancient Extractive Metallurgy Practices: A Case Study from Iron Age Khirbatal-Jariya, Jordan. Journal of Powder Metallurgy \& Mining, 5/1. (2016) 1-5.

https://doi.org/10.4172/2168-9806.1000140

[11] Renkó J. B., Kemény D. M., Nyirő J., Kovács D.: Comparison of cooling simulations of injection moulding tools created with cutting machining and additive manufacturing. MaterialsToday: Proceedings, 12. (2019) 462-469. https://doi.org/10.1016/j.matpr.2019.03.150 